\title{
Toplum kökenli pnömonilerde tanı ve tedavi
}

\section{Diagnosis and treatment of community acquired pneumonia}

\author{
Reyhan ÖZTÜRK1a, Sami KINIKLI², Salih CESUR² \\ ${ }^{1}$ Ankara Kamu Hastaneleri Kurumu, 1. Bölge Sekreterliği, Tıbbi Hizmetler Başkanlığı, \\ ${ }^{2}$ Ankara Eğitim ve Araştırma Hastanesi, Enfeksiyon Hastalıkları ve Klinik Mikrobiyoloji Kliniği, Ankara, TÜRKiYE
}

\section{ÖZET}

Pnömoni, enfeksiyöz bir mikroorganizmanın neden olduğu akciğer dokusunun konsolidasyonu ve inflamasyonudur. Toplum kökenli pnömoni (TKP) yakın zamanlarda hastanede yatmamış ya da düzenli sağlık bakımı almamış kişilerde, akciğerlerde gelişen akut bir enfeksiyondur. Sık rastlanan bir durumdur ve görülme sıklığı yaşlı hastalar arasında daha yüksektir. Toplum kökenli pnömoni ayakta geçirilen hafif bir enfeksiyondan, hastanede yatmayı hatta yoğun bakımı gerektirecek ağır bir hastalığa kadar değiş̧ik varyasyonlarda olabilir ve hala morbidite ve mortalitenin önemli bir nedenidir. Erişkinlerde Streptococcus pneumoniae en sık izole edilen patojendir, çocuklarda ise Respiratuar Sinsityal virüs en sık neden olan viral ajandır. Tedavi stratejileri sıklıkla epidemiyolojik ve demografik veriler ışığında ampiriktir. Bu yazıda toplum kökenli pnömoninin epidemiyolojisi, etiyolojisi, risk faktörleri, tanı ve tedavisi özetlenmiştir.

Anahtar kelimeler: Hastane kökenli pnömoni, etiyoloji, tanısı, tedavisi

\section{ABSTRACT}

Pneumonia is defined as inflammation and consolidation of lung tissue due to infectious microorganisms. Community acquired pneumonia is a syndrome in which acute infection of the lungs develops in persons who have not been hospitalized recently and have had little contact to the health care system. It is a common condition and its attack rates are highest in elderly persons. Community acquired pneumonia can vary from a mild outpatient illness to a more severe disease, requiring admission to a hospital or even an intensive care unit and it remains an important cause of morbidity and mortality. Streptococcus pneumoniae is the most common pathogen and Respiratory Syncitial virus is the most common important viral pathogen in children. Therapeutic strategies are usually empiric, based upon demographic and epidemiologic factors. In this manuscript, epidemiology, etiology, risk factors, diagnosis and treatment of community acquired pneumoniae are summarised.

Key words: Community acquired pneumonia, epidemiology, etiology, diagnosis, treatment

Sorumlu Yazara: Dr. Reyhan ÖZTÜRK, Ankara Kamu Hastaneleri Kurumu, 1. Bölge Sekreterliği, Tıbbi Hizmetler Başkanlığı, Ankara, TÜRKIYE 


\section{Giriş}

Önemli bir ölüm nedeni olan pnömoni 1800 'lü yılların sonundan bu yana modern mikrobiyolojideki gelişmelerle birlikte yoğun olarak incelenmektedir. Bu ilerleme ve antimikrobiyal ajanlardaki gelişmelere rağmen pnömoni hala komplikasyonların ve ölümün önemli bir nedenidir. Toplum kökenli pnömoni (TKP) yakın zamanlarda hastanede yatmamış ya da düzenli sağlık bakımı almamış kişilerde, akciğerlerde gelişen akut bir enfeksiyondur [1].

İleri yaş, baskılanmış immun fonksiyonlar toplum kökenli pnömoni riskini arttırır. Bununla birlikte dental bakım ve yüksek sosyoekonomik düzey riski azaltır. TKP, hala sağlık harcamalarının en önemli nedenidir ve tüm dünyada yüksek maliyete neden olmaktadır [2].

\section{Etiyoloji}

Bakteriyel ve viral ajanlar en sık etiyolojik ajanlardır. Fungal ve parazitik etiyoloji daha nadirdir [2]. Antibiyotiklerden önceki dönemlerde Streptococcus pneumoniae, pnömoninin \%95 nedeniydi. Hala pnömokoklar TKP de sık rastlanan bir etken olmakla birlikte, sıklığı azalmaktadır ve günümüzde Amerika Birleşik Devletleri'nde hastanede yatan hastaların \%10-15'inde görülmektedir. Pnömokokal polisakkarit aşıların erişkinlerde yaygın olarak kullanımı, çocuklar için ulusal pnömokok aşı uygulamaları ve sigara içme oranındaki düşüş bu azalmanın nedenleri arasındadır. Avrupa ve dünyanın diğer bölgelerinde pnömokok aşısının daha az uygulandığı ve sigara içme oranının yüksek olduğu yerlerde pnömokoklar TKP den daha sık sorumlu olmaktadır [1].

Japonya'da toplam 1772 toplum kökenli pnömoni atağının incelendiği çok merkezli bir çalışmada erişkin TKP insidansı $\% 16,9$, hastanede yatış oranı $\% 5,3$ ve hastanede ölüm oranı 0.7/1000 hasta yılı olarak saptanmıştır. İnsidansın yaşla birlikte ciddi şekilde arttığı, 85 yaşın üzerindeki kişilerde, 15-64 yaş arasındaki kişilerden on kat yüksek oranda TKP görüldüğü tespit edilmiştir. Yaşlı hastalarda TKP etiyolojisinde aspirasyon ilişkili pnömoni ilk sırayı alırken, bunu sırasıyla Streptococcus pneumoniae, Haemophilus influenza ve solunum virüslerinin (influenza dahil) izlediği saptanmıştır. Pnömokok ve influenza aşılarının etkin bir şekilde yapılmasının yaşlı hastalardaki pnömoni riskini düşürebildiği sonucuna varılmıştır [3].

Türkiye'de TKP etkenlerinin araştırıldığı bir çalışmada 98 pnömonili olguda TKP etkenlerinin dağılımını sırasıyla; 44 olguda $(\% 44,9)$ Haemophilus influenzae ( $\mathrm{H}$. İnlfuenzae) , 25 olguda $(\% 25,5)$ Streptococcus pneumoniae (S. pneumoniae) ve 12 olguda $(\% 12,2)$ Moraxella catarrhalis (M. catarrhalis) olarak bildirmişlerdir. Çalışmada $\mathrm{H}$. inlfuenzae suşlarının \%6,1'i, M. catarrhalis suşlarının ise tamamının beta-laktamaz enzimi ürettiği saptanmıştır. S. pneumoniae suşlarının \%31,2'sinin E-test yöntemiyle penisiline orta duyarlı olduğu saptanırken, penisiline dirençli suş saptanmamıştır (4). Türkiye'de 1993-1999 yılları arasında yapılan çok merkezli çalışmalarda pnömokok suşlarında orta düzey direnç oranları \%24-40 arasında bildirilmiştir [4-6].
Kurutepe ve ark. [7] yaptıkları çalışmada TKP tanısı konulan 128 olguda etkenlerin dağılımını 32 olguda (\%25) S.pneumoniae ( $n=32,25 \%)$, 9 olguda (\%7) H.influenzae ve M.pneumoniae, 10 olguda $(\% 7,8)$ gram-negatif basil, 6 olguda $(\% 4,7)$ M.catarrhalis $(n=6,4,7 \%), 4$ olguda $(\% 3,2)$ C.pneumoniae, iki olguda $(\% 1,6)$ L.pneumophila ve bir olguda $(\% 1,4)$ Staphylococcus aureus olarak belirlenmiştir. Atipik patojenlerle enfeksiyon 15 olguda $(\% 11,7)$ ve karışık enfeksiyon ise 14 olguda $(\% 10,9)$ bildirilmiştir.

Taşbakan ve ark. [8] 98 sağlık hizmetleri ile ilişkili (nozokomiyal ) pnömoni, 89 TKP pnömoni olmak üzere 187 hastada yaptıkları çalışmada nozokomiyal pnömonili olguların 39'unda $(\% 39,8)$, TKP'li olguların ise 8'inde (\%9) etken saptanmıştır. Nozokomiyal pnömonili hastalarda en sık izole edilen bakteriler Pseudomonas aeruginosa ve Acinetobacter baumannii olarak saptanırken, TKP'li hastalarda en sık izole edilen etkenler S.pneumoniae ve H.influenzae olarak rapor edilmiştir.

Köksal ve ark [9] yaptıkları çok merkezli bir çalışmada 218 pnömonili hastanın 137 (\%62,8)'inde etiyolojik ajan saptanmıştır. En sık izole edilen etkenler sırasıyla; \%14,7 oranında Streptococcus pneumoniae, \%13,8 oranında Mycoplasma pneumoniae ve $\% 10,1$ oranında respiratuvar sinsityal virüs olarak belirlenmiştir. Olguların \%51'inde tek patojen saptanırken, \%12'sinde karışık patojen saptanmıştır. Tipik patojenler olguların \%35,8'inde, atipik patojenler \%20,2'sinde viral etkenler ise \%20,6'sında saptanmıştır. Kronik obstrüktif akciğer hastalığı en sık komorbit hastalık olarak saptanmıştır. Erişkinde S.pneumoniae en sık patojen olarak saptanırken, 65 yaş altındaki hastalarda en sık karşılaşılan atipik pnömoni etkeni M. pneumoniae olarak bildirilmiştir. Yazarlar Türkiye'de TKP ampirik tedavisinin hem pnömokokları hem de M.pneumoniae'yı kapsayan antibiyotik rejimleri olarak düzenlenmesini önermişlerdir.

Haemophilus influenzae (H.influenzae), Staphylococcus aureus (S.aureus), Moraxella catarrhalis (M.catarrhalis) , Pseudomonas aeruginosa (P.aeruginosa) ve diğer gram-negatif basiller TKP nin diğer bakteriyel etkenleridir. Kronik obstrüktif akciğer hastalığı (KOAH) olan hastalarda Haemophilus influenzae ve Moraxella catarrhalis in etken olduğu pnömoni riski yüksektir. P. Aeruginosa ve diğer gram-negatif bakteriler de KOAH ya da bronşiektazisi olan hastalarda özellikle de glukokortikoid kullanıyorlarsa TKP nedeni olabilirler. Mycoplasma pneumoniae ve Chlamydophila pneumoniae (atipik bakteriyel pnömoni) nın etken olduğu TKP lerin insidansı ile ilgili geniş farklılıklar mevcuttur ve bunun bir kısmı kullanılan tanı tekniklerine bağlıdır. Yeni polimeraz zincir reaksiyonu (PZR) teknikleri bu noktada yardımcı olabilir. Legionella türlerinin neden olduğu diğer bir bakteriyel pnömoni belli bazı coğrafik bölgelerde görülmekte ve bazı spesifik maruziyetleri takiben görülmektedir. Karışık mikroaerofilik ve anaerobik bakteriler (oral florada olduğu gibi) sıklıkla balgamın Gram boyamasında görülür ve bu organizmalar hiçbir sebep bulunamayan vakalarda etken kabul edilebilirler [1].

Toplum kökenli metisilin dirençli Staphylococcus aureus cilt ve yumuşak doku enfeksiyonlarının birinci sebebidir fakat aynı 
zamanda bakteriyemi, osteomiyelit ve nekrotizan pnömoni gibi ağır enfeksiyonlara da neden olabilir. Bazı S. aureus türlerinin dünya genelinde sıklıkla gençlerde ve önceden sağlıklı olan bireylerde nekrotizan pnömoniye neden olabildiği saptanmıştır. Yapılan bir çalışmada bağışıklığı yeterli hastalarda ST30-Scc mec IVc-spat 019-PVL pozitif klon nekrotizan pnömoni etkeni olarak saptanmıştır [10].

MRSA'nın neden olduğu toplum kökenli pnömoninin mortalite ve morbidite oranı yüksektir. Toplum kökenli MRSA enfeksiyonlarının yüksek sıklıkla görüldüğü bölgelerde özellikle genç ve sağlıklı bireylerde gelişen kavitasyonlu multilober pnömonide MRSA'dan şüphelenilmelidir. Mortalite büyük oranda septik şok, solunum sıkıntısı ile erken dönemde gelişir. İspanya da yapılan bir çalışmada MRSA pnömonisi ile multilober infiltrasyon, kavitasyon, cilt veya yumuşak doku enfeksiyonu arasında yakın bir ilişki saptanmış. Hastaların hepsinde kan kültürü pozitif saptanmış ve erken mortalite oranı (48. saatten önce) \%19 ve toplam mortalite oranı (30 günden az) \%25 olarak saptanmıştır [11].

MRSA enfeksiyonları dünya çapında artmakla birlikte solunum yolu hemorajisi, MSSA (metisilin duyarlı Staphylococcus aureus) enfeksiyonunda daha sık görülmüştür. Scot ve ark. [12] yaptığı bir çalışmada metisilin direnci dikkate alınmaksızın ölüm oranı \%39 olarak saptanmıştır.

İnfluenza salgınları süresince, influenza virüsünün dolaşımı TKP nin ana nedenidir ve sekonder bakteriyel enfeksiyonların da katkısıyla hastneneye yatışı gerektirecek kadar ciddi bir durumdur. Respiratuar synsityal virüs, parainfluenza virüs, adenovirüs, human metapneumovirüs, coronavirüs ve rhinovirüs TKP li hastalarda yaygın olarak görülür fakat bu organiz- maların ne derecede hastalığa neden olduğu ya da sekonder bakteriyel enfeksiyonlara zemin hazırlayıp hazırlamadığı net değildir. Arap yarımadasında yakın zamanlarda görülen Orta Doğu respiratuar sendrom coronavirüs (MERS-CoV) ve Çin'de saptanan avian (kuş) originli influenza A (H7N9) da TKP ye neden olabilen diğer virüslerdir, her iki virüs de yakın zamanlarda tanımlanmıştır ve başka ülkelere de yayılım göstermiş̧tir [1].

Amerika Birleşik Devletleri'nde yapılan bir çalışmada çocuklarda yıllık pnömoni insidansı 10000 çocukta 15,7 olarak bulunmuş ve iki yaşından küçük çocuklarda insidansın 10000 de 62,2 ile çok daha yüksek olduğu saptanmıştır. Respiratuvar sinvityal virüs beş yaş altı çocuklarda diğer yaş grubundaki çocuklara oranla daha sık görülmüştür (\% 38'e karşılık, \%8). Adenovirüs de benzer şekilde küçük çocuklarda daha sık görülmüş (\%15'e karşılık \%3).Küçük çocuklarda en sık pnömoni nedeni olarak respiratuvar virüsler rapor edilmiştir [13].

Nontüberküloz pnömoni ve endemik alanlarda histoplazma ve koksidioides türleri öksürük, ateş ve yeni pulmoner infiltratla karakterli subakut enfeksiyona neden olabilirler. Coxiella burnetii öksürük, yüksek ateş, şiddetli başağrısı ve yüksek aminotransferaz seviyeleri ile karakterize akut pnömoniye neden olabilir. Hastaneye kabul edilen ciddi TKP' li olgularda enfeksiyöz ve enfeksiyöz olmayan nedenler Tablo 1' de gösterilmiştir.

Toplum kökenli pnömoni etkenleri ile ilgili çalışmaların çoğu üçüncü basamak hastanelerde yapılmıştır ve geniş popülasyonları temsil etmeyebilir, bununla birlikte ayaktan hastalarda yapılan çalışmalarda da benzer mikroorganizmalar saptanmıştır. Titiz çalışmalara rağmen ABD'deki hastaların yaklaşık yarısında neden bulunamamıştır [1].

Tablo 1: Hastaneye kabul edilen ciddi TKP li vakalarda enfeksiyöz ve enfeksiyöz olmayan nedenler(1)*

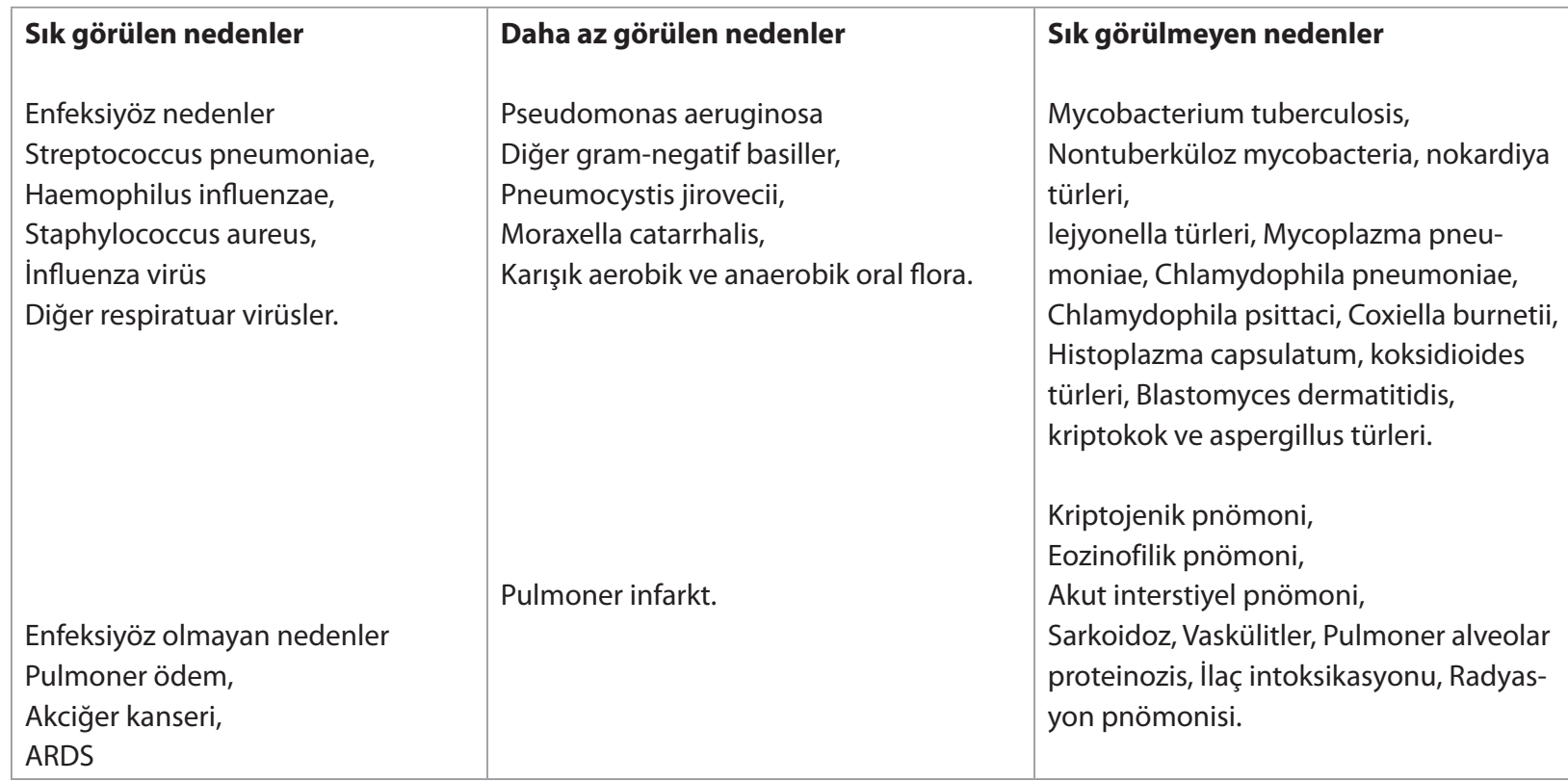




\section{Tanısal Yaklaşım}

Kardiyopulmoner hastalığı olmayanlarda pnömoni tanısı koymak güç değildir. Yaygın semptomlardan, ateş, üşüme titreme, plöritik göğüs ağrısı ve mukopürülan balgamın eşlik ettiği öksürük pnömoniyi düşündürür, fakat bazen toplum kökenli pnömoninin tanısı göründüğünden daha zor olabilir [2]. Klasik pnömoni tablosu postero-anterior (PA) akciğer grafisinde akciğerlerde yeni infiltratla birlikte, ateş, öksürük, balgam artışı, solunum sıkıntısı, konsolidasyonun fizik muayene bulguları ve lökositozla karakterizedir. Konfüzyon ve plöritik göğüs ağrısı sıklıkla görülür. Hastaların bir kısmında (özellikle yaşılarda) öksürük, balgam artışı ya da lökositoz görülmeyebilir ve hastaların yaklaşık \%30'unda (büyük bir çoğunluğunu yaşı hastalar oluşturur) ateşsiz seyredebilir. Yeni akciğer infiltratının saptanması, kronik akciğer hastalığı olan hastalarda, obez olan hastalarda ya da sadece portable göğüs grafisi olan hastalarda zor olabilir ya da infiltrat saptansa bile bu nonenfeksiyöz nedenlere bağlı olabilir. Bir çalışmada TKP nedeni ile hastaneye yatırılmış hastaların \%17'sinde enfeksiyöz bir neden bulunamamış, pulmoner ödem, akciğer kanseri ve diğer karışık nedenler etken olarak saptanmıştır. Klinisyenler ampirik antibiyotik tedavisini başlamadan önce pnömoni benzeri sendroma yol açan nedenleri dikkatlice incelemelidir. Diğer yandan hastaneye yatışı gerektirecek şiddetteki TKP li hastalarda erken antimikrobiyal tedavi olumlu sonuçlara yol açmaktadır [1].

Çoğu TKP de akciğer grafilerinde yamalı tarzda bir konsolidasyon görülür ve bronkopnömoni tanısı alır. Lober ya da multifokal infiltrasyon da diğer iki önemli görünümdür. Klinik uygulamada toplum kökenli pnömoni tanısında infiltrasyonların radyografik olarak incelenmesi altın standarttır. Bazı çalışmacılar lober infiltrasyonun sıklıkla bakteriyel etkenlere bağlı olduğunu bildirmişlerdir ancak lober ya da multifokal infiltrasyonu olan 126 toplum kökenli pnömoni vakasının incelendiği retrospektif bir çalışmada bunların 70 tanesinde Mycoplasma pneumoniae ve 18 tanesinde virüslerin etken olduğu saptanmıştır. Bu nedenle lober ya da multifokal infiltrasyonun mikoplazma ya da virüslere bağlı olup olmadığı sadece radyolojik görüntüye bakarak ayırt edilemeyebilir [14].

Göğüs radyografisi sıklıkla toplum kökenli pnömoni tanısını koymada yeterlidir, bununla birlikte bilgisayarlı tomografi spesifik patojenleri akla getirebilir ve nonenfeksiyöz nedenlerin ayırımını yapabilir. Mycoplasma pneumoniae pnömonisi, Mycobacterium tuberculosis, Pneumocystis jirovecii pnömonisi ve bazı viral pnömoniler bazen spesifik görüntüleme bulguları gösterebilir. Peribronşial nodüller özellikle tomurcaklanmış ağaç görünümünde olurlar ve tamamen enfeksiyona özeldir. Organizasyon bulguları, opasitelerin iç bükey olması, çekilme bronşiektazisi, tüm bronş boyunca hava bronkogramlarının görülmesi, orta dereceli parankimal tahribat organize pnömoniyi akla getirir. Bu nedenle toplum kökenli pnömoni tanısında görüntüleme yöntemlerinin efektif olarak kullanılması önerilmektedir [15].

Kan kültürlerini rehberler sıklıkla önermekle birlikte kan kültür- lerinin TKP tanısındaki hassasiyeti düşüktür. İspanya da yapılan bir çalışmada kan kültürü alınmış 2892 TKP tanılı hastanın kabul edildiği bir çalışmada 297 hastada (\%10) bakteriyemi saptanmış. Bakteriyemi saptanan 30 hastada (saptanan etkenlerin $\% 10^{\prime}$ u) çoklu ilaç dirençli Streptococcus pneumoniae, MRSA, Pseudomonas aeruginosa ve ESBL üreten enterobakteriler saptanmıştır. Çok ilaca dirençli bakterilerde uygunsuz tedavi diğer bakteriler ile karşılaştıııldığında daha sık saptanmış (\%27 ye karşı \%3). Antibiyotik tedavisi bakteriyemiye karşı korur fakat dirençli bakterileri de kapsayan uygunsuz tedavi dirençli bakterilerin neden olduğu bakteriyemi riskini arttırır. Bu nedenle, kan kültürü çok ilaca dirençli bakteriyemi riski olan hastaların tanımlanmasını sağlar ve uygun ampirik antimikrobiyal tedavinin seçilmesinde yardımcı olur [16].

Hastanede yatan toplum kökenli pnömonisi olan hastalarda yapılan bir çalışmada hipoalbüminemi $(<3,5 \mathrm{~g} / \mathrm{dL})$ ve düşük vücut kitle indeksi $(<18,0)$ pnömoni hastalarında daha sık görülmüştür. Çalışmada hipoalbümineminin pnömoni riskini arttırdığı buna karşılık mevsimsel grip aşısının riski azalttığı görülmüştür [17].

Hastalık şiddeti skorları ve yeni tanı metodları prokalsitonin, proadrenomedullin ve bakteriyel testler artan düzeyde TKP tanısında kullanılmaktadır. Bakteriyel antibiyotik direnci oranlarının azalmasını sağlamak için antibiyotik seçimi ve tedavi süresi standartları oluşturulmuştur [2].

\section{Tanısal Yöntemler}

Hastaneye yatışı gerektiren hastalarda, klinisyenler etken olan mikroorganizmayı saptamak için titiz bir çaba göstermelidirler. Böyle bir yaklaşım spesifik patojene yönelik tedavi imkanı sağlar ve de ampirik tedaviye yanıt vermeyen ya da yan etki gelişen hastalarda akılcı bir antibiyotik değişikliğini mümkün kılar. Patojene yönelik antibiyotik tedavisi tedavi başarısını arttırır, bakım maliyetini düşürür ve komplikasyonları azaltır. TKP'si olan hastanede yatan hastalarda balgamın Gram boyaması, kültürü, kan kültürleri, Lejyonella ve pnömokokal üriner antijenlerin test edilmesi ve spesifik risk faktörleri ya da maruziyetleri olan hastalarda Mycoplasma pneumoniae, Chlamydia pneumoniae ve respiratuar virüsler için PZR testi diğer testlere ek olarak önerilir. Düşük serum prokalsitonin konsantrasyonu $(0,1 \mathrm{mg} / \mathrm{lt})$ antibiyotiğe ara vermek ya da kesmek konusunda karar vermeye destek olabilir [1].

Solunum sekresyonların mikroskobik incelemesi, olası etken mikroorganizma hakkında erken yol gösterebilir. Antibiyotik tedavisi başlamadan önce ya da başlandıktan sonraki 6-12 saat içerisinde alınan kaliteli bir balgam örneğinin (her epitelyal hücreye karşılık 10 ve üzeri inflamatuar hücre) Gram boyama ya da kültüründe pnömokokal pnömonili vakaların \%80'inden fazlasında pozitif sonuç saptanır. Antibiyotik başlandıktan sonraki süre arttıkça balgam kalitesi azalır ve örnekte etkeni yakalama şansı da düşer. Hipertonik salinle nebulizasyon (indüklenmiş balgam diye adlandırılır) doğru örnek alma olasılığını arttırabilir [1]. 
Pnömokokal pnömonili yatan hastalarda kan kültürleri \%20 -25 arasında pozitiftir fakat $\mathrm{H}$. influenzae ya da P. aeruginosa nın neden olduğu pnömonilerde düşük oranda Moraxella catarrhalis'in neden olduğu pnömonilerde nadiren pozitiftir. Hematojen seyirli Staphylococcus aureus pnömonilerinde kan kültürü nerdeyse daima pozitifken inhalasyon ya da aspirasyonla oluşan TKP vakalarının sadece \%25'inde pozitiftir [1]. Kan kültürleri toplum kökenli pnömonilerin tanısında sıklıkla tavsiye edilmekle birlikte hastaların yönetimindeki faydası belirgin değildir. Bir çalışmada 390 kan kültürü elde edilen toplum kökenli pnömonili hastanede yatan çocukların altısında $(\% 1,5)$ pozitif bir patojen saptanmıştır. Önceden antibiyotik tedavisi almak, i.v hidrasyon almak, önceden hastanede yatmak gibi durumlar kan kültüründe üreme sonucunu etkileyen faktörlerdir. Kan kültürü alınan hastalarda hastanede kalma süresi 0,8 gün daha fazla bulunmuştur [18].

TKP etkenlerini saptamada yeni tanı metotları önemli hale gelmiştir. İdrar örneklerinde pnömokokal hücre duvarı polisakkaritleri ELISA ile bakteriyemik pnömokokal pnömonili hastalarda \%77-88 oranında saptanırken, bakteriyemik olmayanlarda \%64 oranında saptanmıştır. Daha hassas multıplex capture assay pnömokokal kapsüler polisakkarit klinik kullanım için henüz uygun değildir. Legionella pneumophila serotip 1'in neden olduğu pnömonilerde idrarda lejyonella için antijen ELISA ile \%74 pozitiftir ve hastalığın şiddeti ile sensitivitesi artar. Selektif besiyerleri kullanılarak balgam kültürünün yapılması diğer lejyonella türlerinin saptanması için gereklidir.

Polimeraz zincir reaksiyonu (PZR) respiratuvar (solunum) patojenlerin özellikle de virüslerin saptanmasında oldukça önemli bir yöntemdir. PZR ölçümleri en önemli solunum virüslerine ek olarak M.pneumoniae ve C. pneumoniae gibi atipik pnömoni etkenlerini de saptayabilir. İnfluenza için PZR hızlı antijen testlerinden çok daha hassastır ve tanıda standart haline gelmiştir. Polimeraz zincir reaksiyonu ile hastanede yatan erişkin TKP hastalarının \%20-40'ında bir respiratuar virüs tanımlanmıştır. Ne var ki pozitif saptanan respiratuar virüsün direkt pnömoniye mi neden olduğu ya da hastalarda bakteriyel pnömoniye predispozan mı olduğunu yorumlamak zordur. Dolayısıyla PZR pozitifliği bakteriyel pnömoniyi ekarte ettirmez. Bakteriyel TKP li hastaların yaklaşık \%20'si bir virüsle koinfektedir.

Solunum örneklerinde bakterilerin PZR ile saptanması her zaman hastalık tanısını koydurmaz. Çoğu kez pnömoniye neden olan bakteri üst solunum yollarında kolonize olduktan sonra akciğerlere ulaşır bu yüzden pozitif PZR sonucu hem kolonizasyonu hem de enfeksiyonu yansitabilir [1].

Yeni nükleik asit çoğaltma zeminindeki testler, eş zamanlı bilgisayarlı mikroskopi, yeni nesil dizileme yöntemi ve yüksek ürünlü kütle spektrometri bu testlerdendir. Bu testler maliyet, güvenilirliki gibi nedenlerden dolayı henüz klinik kullanıma girememiştir. Bu nedenle mevcut sınırlı mikrobiyolojik olanaklarla kesinlik kazanmış bir etken bulunana kadar ampirik tedavi bilinen lokal epidemiyolojik verilere dayanmalıdır. Klinisyenler maliyet etkinliğini de dikkatli bir şekilde değerlendirmelidir [19].

\section{Tedavi}

Hastalığın Ciddiyetinin Skorlanması

Skorlama hastalığın şiddetinin belirlenmesine ve hastanın hastaneye yatışının gerekip gerekmediği ve yoğun bakım ünitesinde takibinin gerekip gerekmediğine karar verilmesine yardımcı olur. Kabul edilen kriterler, Pnömoni ağırlık indeksi (Pneumonia Severity Index-PSI), CURB 65 skoru (65 yaş ve üzerindeki hastalarda konfüzyon, BUN, solunum sayısı ve kan basıncı ölçümü) Amerikan enfeksiyon hastalıkları derneği ile Amerikan toraks derneğinin rehberleridir. Hastanın hastaneye yatırılıp yatırılmayacağı kararı doktorun değerlendirmesine bağlıdır fakat bu skorlama sistemi de dahil olmak üzere tüm faktörler gözden geçirilmelidir. Çünkü PSı yaşa bağımlıdır ve gençlerdeki yüksek bir skor dikkatle incelenmelidir [1].

Toplum kökenli pnömonisi olan 105 hastanın incelendiği bir çalışmada CURB-65 skoru 0-2 arasında olan ve yoğun bakım gereksinimi olmayan 25 hastanın 12'sinde daha sonta akut kardiyak olay gelişmiş ve bunları dört tanesinde yoğun bakım gereksinimi gelişmiştir. CURB-65 skoru üç ve üzerinde olan ve yoğun bakım gereksinimi olan 80 hastanın on tanesi akut kardiyak olay nedeni ile ölmüştür. Bir çalışmada hastaneye yatışı gerektiren TKP'li hastalarda akut kardiyak olayların önemli bir morbidite ve mortalite nedeni olduğu saptanmıştır [20].

SMART-COP skoru (Sistolik kan basıncı, multilober infiltratlar, albümin, solunum sayısı, taşikardi, konfüzyon, oksijen ve $\mathrm{pH}$ ) hangi hastanın yoğun bakım takibine gereksinim duyduğunu kararlaştırmak için kullanılır ve raporlarda PSI (\%74) ve CURB65 (\%39) ile karşılaştırıldığında daha hassas (\%92) olduğu bildirilmiştir. Yakın zamanlarda yapılan bir çalışmada hangi hastaların yoğun bakım ihtiyacı olduğunun belirlenmesinde PSI'nin SMART-COP'dan fazla ve CURB-65'ten çok daha fazla hassas olduğu rapor edilmiştir [1].

\section{Ampirik Tedavi Rehberleri}

Toplum kökenli pnömonide ampirik antimikrobiyal tedavi rehberleri tedavinin bir parçasıdır ve hastaneye yatırılan hastalarda kullanılması sonuçların daha iyi olmasına imkan sağlar. Toplum kökenli pnömoni tanısı konulduğu zaman antimikrobiyal tedavi mümkün olan en kısa zamanda ve tanının konulduğu yerde başlanmalıdır. Sağlık bakım kuruluşlarıyla ilk temastan antibiyotik tedavisi başlanana kadar geçen başlangıç hedef periyod 4 saatten 6 saate değiştirilmiştir, çünkü kısmen bu başlangıç hedef periyodda alınan bilgiler düşük kalitede olabilir ve TKP tanısında hatalara ve uygunsuz antibiyotiklerin kullanımına neden olabilirler [1].

Ayaktan takip edilen TKP hastalarının tedavisi genellikle ampiriktir. Enfeksiyon etkeni, tanı testlerinin maliyeti nedeni ile genellikle araştırılmaz. Ek hastalığı ya da yakın zamanlarda antibiyotik kullanım öyküsü olmayan ayaktan takip edilen hastalarda, Amerikan enfeksiyon hastalıkları derneği ve toraks derneği rehberleri başlangıç tedavisinde makrolid (toplumda yüksek derece makrolid direncinin \%25'in altında olması koşuluyla) ve doksisiklin kullanımını önerirler. Ek hastalığı ya da yakın zaman- 
da antibiyotik kullanım öyküsü olan ayaktan takip edilen TKP li hastalarda rehberler tek başına levofloksasin ya da moksifloksasinin ya da bir beta-laktam (örn., amoksisislin-klavulonat) ve makrolidin birlikte kullanımını önerirler. Diğer yandan İngiltere ve İsveç rehberleri ayaktan tedavi edilen hastalarda ampirik tedavide amoksisilin ya da penisilini önermektedir.

Türk Toraks Derneği TKP rehberi 2009 uzlaşı raporuna göre, hastalar; IA, IB, Grup II, Grup IIIA ve Grup IIIB olmak üzere 5 gruba ayrılmıştır. Bu gruplardan Grup IA 'da hastanede yatış ölçütlerini taşımayan, herhangi bir değiştirici faktörü (ileri yaş, komorbidite) bulunmayan hastalar, Grup IB'de bu grupta yer alıp değiştirici faktörü bulunan hastalar, Grup II'de CURB-65 skoru $\geq$ 2 veya PSI değerlendirmesinde IV-V olan ve hastaneye yatırılarak tedavi edilmeyi gerektiren olgular yer alır. Grup III hastalar ise yoğun bakım ünitesine yatırılması ve parenteal antibiyotik tedavisi gerektiren pnömoni olgularını içerir. Grup III A'da Pseudomonas aeruginosa riski olmayan olgular, Grup IIIB'de ise Pseudomonas aeruginosa riski olan olgular yer almaktadır [21].

Pnömoni etkenleri ve tedavi seçenekleri gruplara göre farklılık göstermektedir. Tablo 2'de TKP'si olan Grup I, Grup II ve Grup III hastalarda ampirik tedavi seçenekleri gösterilmiştir.

Tablo 2. Türk Toraks Derneği erişkinde toplumda gelişen pnömoni tanı ve tedavi uzlaşı raporuna göre Gruplara göre tedavi seçenekleri $\left(^{*}\right)$

\begin{tabular}{|c|c|c|}
\hline Grup I & Grup II & Grup III \\
\hline $\begin{array}{l}\text { Hastaneye yatış ölçüterini taşımayan hastalar } \\
\text { CURB-65 <2 (PSI I-III) } \\
\text { Ayaktan tedavi edilir** }\end{array}$ & $\begin{array}{l}\text { Yoğun bakıma yatış ölçütü yok CURB-65 } \geq 2 \\
\text { (PSI IV-V) } \\
\text { Klinikte tedavi edilir }\end{array}$ & Yoğun bakıma yatış ölçütü var \\
\hline $\begin{array}{l}\text { Grup IA değiştirici faktörü yok } \\
\text { Amoksisilin veya Makrolid }\end{array}$ & $\begin{array}{l}\text { 3. kuşak anti-Pseudomonal olmayan } \\
\text { sefalosporin veya beta laktamaz inhibitörlü } \\
\text { aminopenisilin } \\
\text { + Makrolid ya da tek başına yeni floroki- } \\
\text { nolon }\end{array}$ & $\begin{array}{l}\text { Grup IIIA: P.aeruginosa riski yok } \\
\text { 3. kuşak anti-Pseudomonal olmayan se- } \\
\text { falosporin veya beta laktamaz inhibitörlü } \\
\text { aminopenisilin } \\
\text { + Makrolid ya da tek başına yeni florokinolon }\end{array}$ \\
\hline $\begin{array}{l}\text { Grup IB değitirici faktör var } \\
\text { 2-3. kuşak oral sefalosporin veya } \\
\text { amoksisilin+klavunat } \\
\pm \text { Makrolid veya doksisiklin*** }\end{array}$ & & $\begin{array}{l}\text { Grup IIIB: P.aeruginosa riski var } \\
\text { Anti-Pseudomonal beta-laktam + siproflok- } \\
\text { sasin veya aminoglikozid + makrolid }{ }^{* * * *}\end{array}$ \\
\hline
\end{tabular}

$\left.{ }^{*}\right)$ Kaynak 21'den alınmıştır.

(**) Üç günlük antibiyotik tedavisine rağmen ateş düşmezse, hastaneye sevk edilmelidir.

$(* * *) 3$ gr/gün dozunda

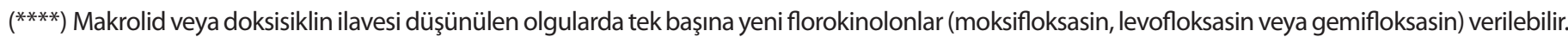

Bazı faktörler ampirik tedavide beta-laktam kullanımının lehinedir. İlk olarak klinisyenlerin çoğu toplumlarındaki pnömokok direnç seviyelerini bilmemektedirler ve S. pneumoniae penisilinlere makrolid ya da doksisiklinden daha hassastır. İkincisi her ne kadar S. pneumoniae' nın neden olduğu TKP insidansı azalsa da S. pneumoniae makrolid ya da doksisikline \%15-30 dirençlidir ve bu durum tedavi başarısızlığı ile sonuçlanabilir.

Tüm dünyada belirli bölgelerde pnömokoklarda makrolid direnci oldukça yüksektir. Üçüncü olarak bir hastada beta-laktama erken yanıt alınmazsa M. pneumoniae gibi atipik etkenler için tedaviye makrolid ya da doksisiklin ilave edilebilir. Amerika Birleşik Devletleri'nde $H$. influenzae izolatlarının üçte biri ve M. catarrhalis izolatlarının çoğu beta-laktamaz üretmektedir ve amoksisilin-klavulanat, özellikle de zeminde bir akciğer hastalığı olanlarda amoksisilin ya da penisiline tercih edilebilir [1].

Yoğun bakım dışı servislerde yatan ve hastaların ortalama yaşının 70 olduğu TKP li hastalarla yapılan bir çalışmada, 656 tane beta-laktam monoterapisi alan hasta, 739 tane beta-laktam makrolid kombinasyonu kullanan hasta ve 888 florokinolon monoterapisi alan hasta retrospektif olarak karşılaştırılmıştır. Bunlarda tedaviyi sürdürme oranları sırasıyla $\% 93, \% 88$ ve
\%92,7 olarak saptanmıştır. Kaba ölüm hızı beta-laktam monoterapisi alan hastalar, beta-laktam ve makrolid kombinasyonu alan hastalar ve florokinolon tedavisi alanlarda sırasıyla; \%9,0 (59 hasta), \%11,1 (82 hasta) ve \%8,8 (78 hasta) olarak saptanmıştır. Ölüm riski beta-laktamla birlikte makrolid kullanımında beta-laktam monoterapisine kıyasla \%1,9 oranında daha yüksek bulunurken, florokinolon monoterapi rejiminde ise beta laktam monoterapisinden \%0,6 oranında daha düşük olduğu belirlenmiştir. Ortalama hastanede kalış süresi tüm gruplarda aynı saptanmıştır. Oral tedaviye geçme süresi kinolon monoterapi rejiminde üç gün iken diğer rejimlerde dört gün olarak bildirilmiştir. Sonuç olarak bu çalışma beta-laktam monoterapisinsin beta-laktam makrolid kombinasyonu ya da kinolon monoterapisinden daha etkisiz olmadığını göstermiş̧tir [22].

Hastaneye yatışı gerektiren ve etkeni henüz belli olmayan TKP'li hastalarda Amerikan enfeksiyon hastalıkları derneği ve Amerikan toraks derneği rehberleri ampirik tedavide ya bir beta-laktam ile bir makrolidin birlikte ya da kinolonun tek başına verilmesini önermektedir. Bu rejimler yaygın olarak kullanılır ve hafif ve orta şiddetteki TKP hastalarının yaklaşık \%90'ında kür sağlar [1]. 
Almanya'da yapılan bir çalışmada Klebsiella türlerinin neden olduğu pnömonide imipenem ya da meropenem direnci hiçbir hastada saptanmamıştır. Ampisilin direnci tüm hastalarda, piperasilin direnci \%75,3 oranında saptanırken karbapenem direnci hiçbir hastada bildirilmemiştir [23].

Yoğun bakımda yatması gereken hastalarda rehberler en azından bir beta-laktamın makrolid ya da kinolon ile kombinasyonunu önermektedirler. Bu durumda üç senaryo akla gelmelidir. Birincisi toplumda influenza aktif ise, semptomların başlamasının üzerinden geçen süre 48 saatten fazla olsa bile TKP li hasta oseltamivir ile tedavi edilmelidir. İnfluenza enfeksiyonu olasılığı yüksek ise tedaviye hızlı antijen testi negatif ise bile devam edilmelidir. influenza virüs için negatif PZR sonucu influenzaya yönelik tedavinin kesilmesine imkan sağlayabilir. Yüksek bakteriyel süperenfeksiyon oranından dolayı seftriakson ve vankomisin ya da linezolid (MRSA için) iyi kalitede bir solunum örneğinin Gram boyamasında bakteri olmadığının ve bakteriyel enfeksiyonun diğer kanıtlarının olmadığının gösterilinceye kadar verilmelidir. İnfluenza şüphesi olan durumlarda damlacık ve temas izolasyonları uygulanmalıdır. İkinci olarak Staphylococcus aureus (S. aureusa) pnömonisi için yüksek riski olan hastalarda (örneğin glukokortikoid kullanan hastalar ya da influenza enfeksiyonu olan hastalar) MRSA tedavisi için vankomisin ya da linezolid tedaviye eklenmelidir. MRSA da dahil S. aureusa ve bununla birlikte S. pneumoniae ve H. İnfluenzae' ya karşı etkili olan seftarolin, seftriakson+vankomisin ya da linezolid gibi MRSA'ya etkili rejimlerin yerini alabilir, bununla birlikte bu ilaç henüz MRSA pnömonisi için FDA onayı almamıştır. Üçüncüsü KOAH ya da bronşiektazi gibi yapısal akciğer hastalığı olan hastalarda (özellikle de glukokortikoid ya da diğer immunsupresif ilaçları kullanıyorlarsa) P. aeruginosa göz önünde bulundurulmalıdır ve bir antipseudomonal betalaktam ya da karbapenem verilmelidir. Amerikan enfeksiyon hastalıkları derneği ve toraks derneği rehberleri pseudomonas türlerinin duyarlılık paternlerinin bilinmesi güç olduğundan dolayı iki antipseudomonal antibiyotik kullanımını önermektedirler. Başlangıç tedavisi ampirik olabilir fakat enfeksiyon nedeni saptandıktan sonra antibiyotikler etkene uygun hale getirilmelidir [1].

Yakın zamandaki retrospektif çalışmalar MRSA pnömonisi olan hastaların tedavisinde linezolidin vankomisinle karşılaştırıldığında daha etkili olduğunu göstermiş. MRSA'ya karşı etkili televansin, seftarolin ve seftobiprole gibi ilaçlarla ilgili çalışmalar mevcuttur fakat toplum kökenli MRSA pnömonili hastalarda en iyi terapötik ajanla ilgili kısıtlı bilgiler mevcuttur. Linezolid MRSA ya bağlı ventilatör ilişkili pnömonide daha iyi bir tedavi ajanı gibi görülmekle birlikte MRSA pnömonisinin diğer formlarında gerekli olup olmadığının netleştirilmesi gerekir [24].

Tedizolid fosfat oksazolidinon grubunda yakın zamanda bulunan ve FDA tarafından akut bakteriyel cilt ve cilt ekleri enfeksiyonlarında onaylanan bir ön ilaçtır ve invivo fosfatazlarla aktif hale gelir. Tedizolid etkisini 50 s rRNA nın 23 s alt ünitesini etkileyerek protein sentezini inhibe etmek yoluyla gösterir. Tedizolid tüm stafilokok türleri, enterokoklar ve streptokoklarakarşı, MRSA, VRE gibi dirençli suşlara karşı linezolidden 4-8 kat daha potenttir. Ayrıca linezolid dirençli suşlara da etkilidir. Tedizolid şimdilik hastane kökenli pnömoni ve ventilatör ilişkili pnömoni tedavilerinde Faz- 3 klinik çalışma aşamasındadır [25].

\section{Amprik tedavi}

Amerikan enfeksiyon hastalıkları derneği ve toraks derneği rehberleri TKP nin en önemli etkenlerine karşı standart bir uygun antimikrobiyal kılavuz geliştirmeye çalışmaktadır. Bununla birlikte mevcut bulgularla etken organizma saptanamayabilir, tıbbi literatür klinik bulguları tanı ve tedavinin seçimi konusunda destekleyebilir. Klinisyenin yaklaşımı uygun antimikrobiyal rejimi seçmek, bir yanda tedavi hataları ile diğer yanda tüm olası etkenleri kapsamaya çalışan aşırı tedavi arasındaki dengeyi sağlamaktır [1]. Tablo 3'te klinik özelliklerle ilişkili spesifik TKP nedenleri gösterilmiştir.

Tablo 3. Klinik özelliklerle ilişkili spesifik TKP nedenleri*

Tipik bakteriyel ya da legionella pnömonisini destekleyenler Hiperakut klinik

Septik şokla birliktelik

Üst solunum yolu bulgularının yokluğu

İlk üst solunum yolu hastalığını takiben akut kötüleşme (bakteriyel süperenfeksiyon gelişen viral enfeksiyonu akla getirir) Beyaz küre sayısının $>15.000 / \mathrm{mm}^{3}$ ya da $\leq 6000 / \mathrm{mm}^{3}$ olması ve band formunun artması

Segmental ya da lober konsolidasyon

Prokalsitonin seviyesinin $\geq 0,25 /$ lt olması

Atipik bakteriyel (mycoplasma ya da chlamydophila ) pnömoniyi destekleyenler

Tipik bakteriyel pnömoniye neden olan faktörlerin yokluğu Ailesel yoğunlaşma

Akut kötüleşme olmaksızın öksürüğün 5 günden uzun sürmesi

Balgam artışı olmaması

Normal ya da hafif yükselmiş beyaz küre sayısı

Prokalsitonin seviyesinin $\leq 0,1 /$ It olması

Nonbakteriyel (viral) pnömoniyi destekleyenler

Tipik bakteriyel pnömoniye neden olan faktörlerin yokluğu

Hasta kişi ile temas

Başvuruda üst solunum yolu bulguları

Yama tarzı pulmoner infiltrasyon

Normal ya da hafif yükselmiş beyaz küre sayısı

Prokalsitonin seviyesinin $\leq 0,1 /$ lt olması

Influenza pnömonisini destekleyenler

Tipik bakteriyel pnömoniye neden olan faktörlerin yokluğu

Toplumda influenza aktivasyonu

Ani grip benzeri sendrom başlangıcı

İnfluenza için pozitif tanı testi

(*) Kaynak 1'den alınmıştır. 
Akut başlayan üşüme ve ateş, öksürük, balgam artışı, plöritik göğüs ağrısı, band formundaki artışla birlikte yüksek ya da düşük lökosit sayısı, segmental ya da lober konsolidasyonu olan ya da serum prokalsitonin seviyesi $0,25 \mu \mathrm{g} / \mathrm{lt}$ den fazla olan hastalar tipik bakteriyel pnömoniye uygundur, örneğin pnömokokal pnömoni. Bu tür hastalar hastaneye yatırılmalı (PSI indeksine göre endikasyon varsa) ve beta-laktam (örneğin, seftriakson ya da ampisilin-sulbaktam) ve makrolid kombinasyonu ile ya da kinolonla (levofloksasin ya da moksifloksasin) tedavi edilmelidir. P. aeruginosa enfeksiyonu için risk yükselmişse bir antipseudomonal bata-laktam (örneğin, sefepim ya da piperasilin-tazobaktam) kullanılır. Amerikan enfeksiyon hastalıkları derneği ve toraks derneği rehberlerinin (iki antipseudomonal ajan kullanmayı önerirler) aksine bazı araştırmacılar ikinci antipseudomonal ajanı sadece ağır hastalığı olanlarda önermektedir. Hafif enfeksiyonu olan ve hastaneye yatışı gerektirmeyen hastalarda amoksisilin-klavulanat uygun bir parenteral beta-laktam olarak verilebilir. Kinolonlar akılc kullanılmalı ve mevcut ek hastalığı olan ayaktan hastalarda ya da yakın zamanda farkı bir grup antibiyotik kullanmış olan hastalarda kullanılmalıdır. Diğer yandan Amerikan Enfeksiyon Hastalıkları Derneği ve Toraks Derneği rehberlerinin aksine bazı araştırmacılar pnömokokal direnç yüzünden tipik bakteriyel pnömoniyi destekleyen bulguları olan ayaktan hastalarda tek başına doksisiklin ya da azitromisin kullanmayı önermemektedir [1]. TKP'de ampirik tedavi Tablo 4'de gösterilmiştir. Polonya'da yapılan bir çalışmada 7 gün $2 \times 500 \mathrm{mg}$ i.v levofloksasin tedavisinin daha önce inefektif antibakteriyel tedavi almış toplum kökenli pnömonisi olan hastalarda efektif ve koruyucu olduğu saptanmış [26].

Eğer toplumda influenza aktif ve semptomlar da uygunsa (ani başlangıç, ateş, öksürük ve miyalji) influenza için PZR sonucu negatif çıkana kadar oseltamivir verilmelidir. Bu tür hastalarda PZR'da influenza dışındaki respiratuvar virüslerin saptanması antibiyotiksiz takip edilmeyi destekler. Akut kötüleşme olmaksızın hafif derecede ateşi ve 5 gün ve daha uzun süren nonprodüktif öksürüğü olan genç erişkinlerde özellikle de aile içi vaka kümelenmeleri varsa M.pneumoniae büyük olasılıktır. Mycoplasma pneumoniae enfeksiyonunun bir makrolidle tedavi edilmesi özellikle de virüs testleri negatif ise uygun bir tedavi yaklaşımıdır [1].

Ciddi toplum kökenli pnömonisi olanlarda tedavi başarısızlı̆ı̆ aşırı inflamatuar cevap ile ilişkilidir. Kortikosteroidler belki bu hastalarda sitokin salııımını düzenlerler fakat bu tedavi tartışmalıdır. İspanya'da üç tane eğitim hastanesinde ağır toplum kökenli pnömoni ve yüksek inflamatuar yanıtı olan hastalar (CRP değeri $150 \mathrm{mg} / \mathrm{L}$ den yüksek olan) hastalar değerlendirilmiştir. Hastalara $0,5 \mathrm{mg} / \mathrm{kg}$ metilprednizolon 12 saate bir intravenöz ya da plasebo 5 gün boyunca hastaneye kabul edildikleri 36 saat içinde başlanmıştır.
Şiddetli TKP' si ve yüksek inflamatuar cevabı olan hastalar arasında akut metilprednizolon kullanımı plasebo ile karşılaştııılığında tedavi başarısızlığını azaltmıştır. Bu bulgular bu tür klinik popülasyonda antibiyotik ve steroidin birlikte kullanılmasını destekler niteliktedir Kortikosteroid tedavisi tedavi başarısızlığı riskini azaltmış, ancak hastanede ölümler iki grup arasında farklı değilmiş. Hiperglisemi steroid alan grupta \%18, diğer grupta \%12 oranında görülmüş ve istatiksel olarak anlamlı saptanmamıştır [27].

Toplum kökenli pnömonisi olan bir hasta hastaneye yatırıldığında ve etken mikroorganizma saptanamadığında, klinisyenlerin çoğu bakteriyel pnömoni olduğunu varsayarak geniş spektrumlu antibakteriyel tedavi başlamaktadır. Bazı çalışmalar biyomarkırların kullanımının bakteriyel ve bakteriyel olmayan pnömoni ayırımını yapabileceğini öne sürmektedir. On dört randomize kontrol içeren bir meta-analizde, antibiyotik kullanımında prokalsitonin rehberliği, mortalite ya da tedavi hatasına neden olmaksızın antibiyotik kullanımında azalmayla ilişkili bulunmuştur. Bazı hastalarda prokalsitonin seviyesini arttıran başka nedenler de vardır ve bu testler antibiyotik vermemeye karar vermede göz önünde bulundurulan birkaç faktörden sadece biridir [1].

Yaşlı hastalarla genel popülasyon arasında antibiyotik etkinliğinin karşılaştııılığı bir çalışmada anlamlı bir fark saptanmamıştır [28]. Streptococcus pneumoniae, pnömoni ve invaziv pnömokokal hastalıkların önemli bir etkenidir. 23 bileşenli polisakkarit aşının 65 yaş ve üstü hastalarda invaziv pnömokokal hastalıktan korumaya etkili olduğu fakat aşılama ve hastanede tedavi edilen pnömoni arasında koruyucu bir etki olmadığı belirlenmiştir. Diğer bir değişle 23 bileşenli polisakkarit aşı pnömokokal hastalığın invaziv formlarının önlenmesine etkili olmakla birlikte hastanede tedavi edilen pnömoni olgularına karşı etkili olmadığı saptanmıştır [29].

\section{Tedavi süresi}

Yedi gün ve altında süren tedavi ile 8 gün ve üzerindeki tedavileri karşılaştıran bir meta-analiz çalışmada sonuçlar arasında bir fark olmadığı görülmüş ve prospektif çalışmalar 5 günlük tedavinin de 10 günlük tedavi kadar etkili olduğunu göstermiştir. Buna rağmen klinisyenler TKP tedavi süresini sıklıkla 1014 gün süre ile uygulamaktadır. Antibiyotik yönetimi ile yetersiz antibiyotik tedavisi arasındaki dengeyi sağlayan sağduyulu bir yaklaşımla tedavi 5 ila 7 gün arasında uygulanabilir.

Hematojen S. aureus pnömonisi en az 4 hafta tedavi edilmelidir fakat bu organizmanın neden olduğu segmental ya da lober pnömonide 2 hafta tedavi yeterlidir. Kaviteli pnömoni ve akciğer absesi genellikle birkaç hafta tedavi edilir; bazı uzmanlar tedaviyi kavite düzelene kadar uzatırlar. Toplum kökenli pnömonili hastalarda uygun tedaviye cevapsızlık yeniden ayrıntılı olarak incelenmeli ve alternatif antibiyotikler seçilmelidir [1]. 
Tablo 4. Toplum Kökenli Pnömoninin ampirik tedavisi*

\begin{abstract}
Ayaktan hastalar
Tipik bakteriyel pnömoniyi düşündüren bulgular: Amoksisilin klavulonat eğer lejyonella türleri kanaati varsa azitromisin eklenerek; veya yerine levofloksasin ya da moksifloksasin kullanılabilir.

İnfluenza pnömonisini düşündüren bulgular varsa:Oseltamivir ve sekonder bakteriyel enfeksiyonların takibi.

İnfluenza dışı viral pnömoni düşündüren bulgular varsa: Semptomatik tedavi

Mycoplasma ya da chlamydophila pnömonisini düşündüren bulgular varsa: Azitromisin ya da doksisiklin.
\end{abstract}

\section{Yatan hastalar}

Başlangıç ampirik tedavi: Beta-laktam (seftriakson, sefotaksim ya da seftarolin) + azitromisin; veya yerine levofloksasin ya da moksifloksasin kullanılabilir.

İnfluenza olasılığı varsa: Oseltamivir,

Sekonder bakteriyel enfeksiyonlarla komplike olan influenza olasılığı varsa:Seftriakson ya da sefotaksim ile birlikte vankomisin ya da linezolid oseltamivire eklenir

Staphylococcus aureus olasılığı varsa: Vankomisin ya da linezolid antibakteriyel tedaviye eklenir.

Pseudomonas pnömonisi olası ise: Antipseudomonal beta-laktam (piperasilin-tazobaktam, sefepim, meropenem ya da imipenem-silastatin) + azitromisin.

\section{$\left.{ }^{*}\right)$ Kaynak 1'den alınmıştır.}

\section{İmmünomodülatör ilaçlar}

Makrolidler, önemli hücre içi sinyal yollarını inhibe ederler ve sırasıyla inflamatuar sitokinlerin üretimini azaltan ve adezyon moleküllerinin ekspresyonunu yapan faktör KB ve aktivatör protein 1 gibi transkripsiyon faktörlerinin üretimini baskılarlar. Retrospektif çalışmaların hepsi değilse de çoğu pnömokokal pnömoni ya da tüm TKP etkenlerinde beta-laktam antibiyotiğe makrolid eklenmesinin inflamatuar yanıtı baskılayarak mortalite ve morbiditeyi azalttığını göstermiştir. Statinler 3-hidroksi3-metil glutaril koenzim A (HMG-CoA) redüktaz sentezini bloke ederek, farnesil pirofosfat ve geranilgeranil pirofosfat (G proteinlerinin aktivasyonu için ihtiyaç duyulan) sentezini inhibe etmek suretiyle inflamatuar yanıtı baskılarlar. Gözleme dayalı çalışmalar başlangıç sırasında statin kullanan pnömonili hastalarda, koroner arter hastalıkları ile ilişkili ek hastalıkları olmasına rağmen daha iyi sonuçları olduğunu göstermiştir. TKP olabilecek hastalarda makrolid ve statinlerin bu etkilerini inceleyen randomize çalışma sonuçları yoktur. Makrolidlerin potansiyel faydaları, azitromisin kullanan hastalardaki hafif yükselmiş ani kardiyak ölüm riski ile dengelenmiştir. Bununla birlikte diğer çalışmalar çelişkili sonuçlar göstermiştir. Ventilatör ilişkili pnömonisi olan hastalarda simvastatin tedavisi ile ilgili randomize bir çalışma, 28 gün mortalitesi üzerine faydası olmadığı için erken sonlandırılmıştır [1].

\section{Enfeksiyöz olmayan komplikasyonlar}

İnfluenza pnömonisi ve bakteriyel pnömoninin herbirinin akut kardiyak olayla güçlü bir ilişkisi olduğu bildirilmiştir. TKP tanısı ile takip edilen hastaların \%7-10'unda miyokard infarktüsü ve yeni majör aritmiler (en sık atriyal fibrilasyon) görülmüş, yak- laşık \%20'inde kardiyak hasarda kötüleşme, \%25 hastada bu komplikasyonların bir ya da birkaçı görülebilir. Miyokardiyal iskemi, pulmoner inflamasyonda salınan sitokinlerin hasarlı aterosklerotik plaktaki etkisi ile ilişkili olabilir. Atriyal fibrilasyonun mekanizması tam net değildir, bu aritmi birkaç hafta içinde kendiliğinden düzelir. Kardiak hasar oksijenasyondaki azalmanın kalp üzerindeki stresi arttııı etkisinden de kaynaklanabilir. Bu kardiak etkiler artmış mortalite ile ilişkilidirler [1].

\section{Sonuç}

Çalışmalar daha önceden pnömokok aşısı yapılmasının toplum kökenli pnömonilerde sonuçların daha iyi olmasını sağladığını göstermiş̧ir. İnfluenza aşısının ise TKP sonuçlarını bağımlı ya da ek olarak etkileyebileceğini göstermiştir. Önceden pnömokok aşısı olmak hastanede yatış süresini kısaltmadığını ya da yatan hastalarda mortalite ya da respiratuar komplikasyonları azaltmadığı görülmüştür. Düşük bakteriyemi riski pnömokok aşısı ile ilişkili bulunmuştur. Aşılanan grupta mortalitede anlamlı bir azalma olmamakla birlikte hem grip hem pnömokok aşısını olanlarda hastanede kalış süresinde hiç aşılanmayanlara kıyasla \%10'luk bir azalma olduğu bildirilmiştir [30].

Hastaneye yatırılan TKP hastalarında 30 günlük mortalite oranı yaklaşık \%10-12'dir. Hastaneden taburcu olduktan sonra hastaların \%18'i 30 gün içinde tekrar hastaneye kabul edilmektedir. Bazı hastalar özellikle yaşlı olanların önceki sağlık durumlarına dönmeleri birkaç ayı alabilir [1].

Sonuç olarak, TKP ile ilgili hala çözülmemiş problemler mevcuttur. Titiz çalışmalara rağmen hastaların yarısında etken organizma saptanamamaktadır. Bunların ne kadarının tipik ya da atipik bakteriyel patojenler, oral flora, virüsler ya da diğer patojenlere bağlı olduğu net değildir. PZR kullanımının artması, diğer patojenlerin yanı sıra lejyonella, chlamidophila ve mikoplazma türlerinin tanınmasını sağlar. Polimeraz zincir reaksiyonu sensitif diagnostik testler, uygunn tadvinin başlanmasını ve ampirik tedavi kullanımının azalmasını sağlar. Bakterilerde antibiyotik direncindeki artış, etkili bir tedavi seçimini daha da zorlaştırmaktadır. TKP tedavisinde makrolidlerin ve statinlerin antiinflamatuar etkilerinin yararlı olup olmadığının anlaşılması için randomize çalışmalara ihtiyaç vardır [1].

Ayrıca, TKP'li hastalarda ampirik tedaviye karar vermekte olası etkenlerin bölgesel dağılımları, antibiyotik duyarlııkları ve hastalara ilişkin risk faktörleri göz önüne alınarak tanı ve tedavi rehberlerinin oluşturulması ve güncel veriler ışığında gözden geçirilmesi de akılcı bir yaklaşım olacaktır.

\section{Çıkar çatışması ve Finansman Beyanı}

Bu çalışmada çıkar çatışması ve finansman destek alındığı beyan edilmemiştir.

\section{Kaynaklar}

1. Longo DL. Community acquired pneumonia. N Eng J Med 2014; 371: 1619-28.

2. Choby BA, Hunter P. Respiratuar Infections:Community-Acquired pneumonia. FP Essent 2015; 429: 11-21. 
3. Morimoto K, Suzuki J, İshifuji T, Yaegashi M, Asoh N, Hamashige $\mathrm{N}$. The burden and etiology of community onset pneumonia in the aging Japanese population: a multicenter prospective study. PloS One 2015;10: e0122247. doi: 10.1371/journal. pone.0122247.

4. Ozyilmaz E, Akan OA, Gulhan M, Ahmed K, Nagatake T. Major bacteria of community-acquired respiratory tract infections in Turkey. Jpn J Infect Dis 2005; 58: 50-2.

5. Gür D, Güçiz B, Hasçelik G, et al. Streptococcus pneumoniae penicillin resistance in Turkey. J Chemother 2001; 13: 541-5.

6. Sener B, Günalp A. Trends in antimicrobial resistance of Streptococcus pneumoniae in children in a Turkish hospital. J Antimicrob Chemother 1998; 42: 381-4.

7. Kurutepe S, Ecemiş T, Ozgen A, et al. Investigation of bacterial etiology with conventional and multiplex PCR methods in adult patients with community-acquired pneumonia. Mikrobiyol Bul 2012; 46: 523-31.

8. Taşbakan MS, Bacakoğlu F, Başoğlu OK, et al. The comparison of patients with hospitalized health-care-associated pneumonia to community-acquired pneumonia. Tuberk Toraks 2011; 59: 348-54.

9. Köksal I, Ozlü T, Bayraktar O, et al. TUCAP Study Group. Etiological agents of community-acquired pneumonia in adult patients in Turkey; a multicentric, cross-sectional study. Tuberk Toraks 2010; 58: 119-27.

10. Fernandez S, Murzicato S, Sandoval O, Fernandez C, Mollerach M. Communıty-acquired necrotizing pneumonia caused by methicilline-resistant Staphylococcus aureus ST 30 Scc mec IVcSpat019-PVL positive in San Antonio de Acero, Argentina. Rev Argent Microbiol 2015; 47: 50-3.

11. Obed M, Garcia C, Pessacq P, Mykietiuk A, Visaus D. Clinical features and outcome of community-acquired methicilline-resistant Staphylococcus aureus pneumonia. Enferm Infecc Microbiol Clin 2014; 32: 23-7.

12. Sicot N, Khanafer N, Meyssonnier V, Dumitrescu O, Tristan A. Methicillin resistance is not a predictor of severity in community-acquired Staphylococcus aureus necrotizing pneumonia-results of a prospective observational study. Clin Microbiol Infect 2013; 19: E142-8.

13. Jain S, Williams DJ, Arnold SR, Ampofo K,Bramley AM. Community-acquired pneumonia requiring hospitalization among US children. N Eng J Med 2015; 372: 385-45.

14. Guo WL, Wang J, Zhu LY, Hao CL. Differantiation between Mycoplasma and viral community-acquired pneumonia in children with lobe or multifoci infiltration:a retrospective case study. BMJ Open 2015; 5: e006766. doi: 10.1136/bmjopen-2014-006766.

15. Nambu A, Ozawaka K, Kobayashi N, Tago M. Imaging of community-acquired pneumonia: Roles of imaging examinations, imaging diagnosis of spesifik pathogens and discrimination from noninfectious diseases. World J Radiol 2014; 6: 779-93.

16. Torres A, Cilloniz C, Ferrer M, Gabarrus A, Polverino E. Bacteremia and antibiotic-resistant pathogens in community acquired pneumonia risk and prognosis. Eur Respir J 2015; 45: 1353-63.
17. Washio M, Kondo K, Fujisawa N, Harada E, Tashito H. Hypoalbuminemia, influenza vaccination and other factors related to the development of pneumonia acquired outside hospitals in southern Japan: A case-control study. Geriatr Geronto Inf 2015; 11: 1088-93.

18. Mc Culloh RJ, Koster MP, Yin DE, Milner TL, Ralston SL. Evaluating the use of blood cultures in the management of children hospitalized for community-acquired pneumonia. PLOs One 2015; 10: e0117462. doi: 10.1371/journal.pone.0117462.

19. Basnayake TL, Waterer GW. Rapid diagnostic tests for defining the cause of community-acquired pneumonia. Curr Opin Infect Dis 2015; 28: 185-92.

20. Dutt TS, Tousheed SZ, Mohan BV. Community acquired pneumonia and cardiac diseases: a fatal association. Indian J Chest Dis Allied Sci 2014; 56: 153-6.

21. Özlü T, Bülbül Y, Alataş $F$ ve ark. Türk Toraks Derneği erişkinlede toplumda gelişen pnömoni tanı ve tedavi uzlaşı raporu. 2009; Edi. Türk Toraks Dergisi, 2009; 10 (Ek 9): 1-18.

22. Postma DF, Van Werkhoven CH, Van Elden LJ, Thijen SF, Hoepelman Al. Antibiotic treatment strategies for community-acquıred pneumonia in adults. N Eng J Med 2015; 372: 1312-23.

23. Yayan J, Ghebremedhine B, Rasche K. No carbapeneme resistance in pneumonia caused by Klebsiella species. Medicine (Baltimore). 2015; 94: e527.

24. Peyrani P, Ramirez J. What is the best therapeutic approach to methicilline-resistant Staphylococcus aureus pneumonia? Curr Opin Infect Dis 2015; 28: 164-70.

25. Zhanel GG, Love R, Adam H, Golden A, Zelenitsky S. Tedizolid. A novel oxazolidinone with potent activity against multidrug-resistant gram-positive pathogens. Drugs 2015; 75: 253-70.

26. Karwat KJ, Grabczak M, Chazan R. Efficacy and safety of levofloxacin treatment of community-acquired pneumonia in hospitalized patients. Pneumonol Alergol Pol 2006; 74: 77-9.

27. Torres A, Sibila O, Ferrer M, Polverino E, Menendez R. Effect of cortocosteroids on treatment failure among hospitalized patients with severe -community-acquired pneumonia and high inflammatory response: A randomized clinical trial. JAMA 2015; 313: 677-86.

28. Avni T, Shiver-Ofer T, Leibovici L, Tacconelli E, DeAngelis G. Participation of elderly adults in randomized controlled trials addressing antibiotic treatment of pneumonia. J Am Geriatr Soc 2015; 63: 233-43.

29. Leventer-Roberts M, Feldman BS, Brufman I, Cohen-Stavi CJ, Hoshen M. Effectivenes of 23-valent pneumococcal polysaccharide vaccine against invasive disease and hospital-treated pneumonia among people aged $\geq 65$ : a retrospective case-control study. Clin Infect Dis 2015; 60: 1472-80.

30. Li C, Gubbins PO, Chen GJ. Prior pneumococcal and influenza vaccinations in hospital outcomes for community acquired pneumonia in elderly veterans. J Hosp Med 2015; 10: 287-93. 